\title{
8. Early tracking and competition - A recipe for major inequalities in Hungary
}

\author{
Dániel Horn, Tamás Keller, and Péter Róbert
}

\section{INTRODUCTION}

One of the earliest studies based on Robert Mare's (1981) concept of and statistical approach to educational choices and transitions was an analysis based on 1973 data from the Hungarian Central Statistical Office (Simkus and Andorka 1982). Since then, a great variety of sociological and economic studies have investigated educational inequalities, school choice, and school transitions in Hungary. Hungary is not just interesting in itself because it has one of the most unequal education systems in the OECD with an extraordinarily high impact of family background on test scores (OECD 2010a). It is also unique due to its educational institutional setup that hinders intergenerational mobility and increases intra-generational inequalities. There are evidently several potential sources of educational inequalities (see introductory chapter of the volume). Hungary combines quite a large number of these and probably has an 'influential' system of institutions for increasing inequalities. This makes it essential to understand their role. As we argue below, it is a combination of competition between schools on the primary level, heavy tracking on the lower and upper secondary level, and withinschool differentiation that has led to the current, rather unequal system.

The goal of this chapter is to answer the three main research questions highlighted in the first chapter of this volume.

1. How are students allocated to different types of lower and upper secondary education (educational differentiation)?

2. Is the first students' allocation permanent? How far do students get a second chance to shift between types of secondary education and why?

3. What are the short- and long-term effects of attending different types of secondary education? 


\section{DESCRIPTION OF THE SYSTEM}

Although earlier changes in the Hungarian school system have already been described and summarized (Bukodi and Róbert 2008), there have been many recent changes that could influence the allocation of students between and within schools. Historically, Hungary can be considered as one of the variations of the so-called German school model similar to most CentralEastern European countries. During the Communist era, pupils spent eight years in the non-tracked primary and lower secondary school (általános iskola) and three to four years in the tracked upper secondary school (középfokú iskola). Before the upper secondary level at the age of 14, they had to make an important choice on whether to enter an academically oriented secondary track (gimnázium), a more vocationally oriented secondary track (szakközépiskola), or an apprenticeship/vocational training track (szakmunkásképzés or later szakiskola). Whereas the former two allowed students to continue to the tertiary level, the latter was an academic dead-end leading only to the possibility of entering the labour market. As in most systems of the Soviet type, the curriculum was highly standardized and there was no variation in textbooks or teaching materials. For the academically and vocationally oriented secondary level tracks, there was a final exam (érettségi) at the end of secondary education that was also standardized. Significant changes occurred in the school system during the post-Communist transition. However, the last two and a half decades can be divided into the two following periods.

\section{The Pre-2011 Period}

In line with the general democratization and marketization processes of the post-Communist transition, the school system in Hungary became one of the most decentralized in Europe with highly increased school-level autonomy (OECD 2004, D6 indicators). The centralized and standardized curriculum was replaced by a large variety of school programmes. Schools had freedom of choice in terms of educational programmes and methods and could draw on a large variety of textbooks because of the emerging market for different teaching materials. As in other fields, a school market and consequently competition between schools became a main feature of the Hungarian educational system on both the primary and secondary level. Increasing competition had a 'quantitative' as well as a 'qualitative' aspect. In quantitative terms, the number of students decreased rapidly due to a demographic decline in the size of the post-transition school-entry cohorts that created free capacities within schools. The other 'qualitative' aspect was that schools, utilizing their widespread autonomy, competed for the 'better' 
students in order to achieve a better class composition in their school. The best and most innovative schools used their freedom and autonomy to develop new school tracks, programmes, and curricula that would appeal to better students.

Another source of school differentiation was the change in the education provider. During the Communist era, almost all schools were public. ${ }^{1}$ From the 1990s onwards, the non-public sector started to emerge. The number of church-funded religious schools started to increase drastically, and several privately funded schools were also established. After roughly two decades, by 2012 , about 20 per cent of primary schools were non-public and about three-quarters of these were of a denominational character. In terms of enrolment, about 14 per cent of pupils were studying full-time in non-public schools. The majority of these pupils were enrolled in religious schools and less than 1.5 per cent in private schools. When looking at the academic secondary schools, 40 per cent of these schools were non-public and more than half of them were of a denominational character in 2012. In full-time education, about 26 per cent of students studied in non-public institutions and about four-fifths of these studied in religious schools (Ministry of Human Resources 2013). The public-private divide can also be seen as a kind of tracking in the Hungarian school system, as shown by Dronkers and Róbert (2004).

\section{The Post-2011 Period}

Since 2011 with the passing of the CXC/2011. Law on Public Education, ${ }^{2}$ the democratization and marketization process (with its pros and cons) has been halted and reversed. Whereas previously, local governments ran their own schools, it is now the national school provider that hires and fires teachers, allocates resources, and decides on the newly centralized curriculum. Choices in the available textbooks have also plummeted. The previous per-student lump-sum financing has been replaced by a per-teacher lump-sum financing with a fixed teacher-student ratio. The regulations for opening a new religious school or taking over a public school have been eased. Consequences of the new system cannot be studied yet due to the lack of data, but we can expect some decline in competition between schools on the primary level (due to the centralization process), but an increase in religious tracking on the lower- and upper-secondary level. Basic rules of earlytracking on the lower secondary level are still the same.

Nevertheless, due to the lack of available data, all our analysis below concerns the pre-2011 status of the Hungarian education system. 


\section{MAIN MECHANISMS FOR DIFFERENTIATION}

Although in theoretical terms, the Hungarian school system can be characterized by four forms of differentiation (see Table 8.1), we shall examine only three of these possible forms empirically because of data limitations. The empirical section below considers the two external differentiation mechanisms (both the formal and the informal) and the internal-formal differentiation (within school specializations). It will not consider the internal-informal differentiations because hardly any empirical evidence is available on these. ${ }^{3}$

There are three major sources of external and formal differentiation: tracking on lower secondary level, tracking on upper secondary level, and the selection of students between public and non-public schools. Whereas these mechanisms are regulated forms of differentiation that are recognized by law and can also be seen in school certificates/qualifications, the competition between otherwise similar schools on the primary level can be considered as an informal mechanism of differentiation. The operation of both of these external differentiation mechanisms is well described and well researched empirically (e.g. Kertesi and Kézdi 2010a, 2013; Horn 2013).

One type of external-formal differentiation is vocational tracking on the upper secondary level at age 14. This was also possible during the Communist era. Some have argued that the school system was the main transmitter of social inequalities during that period. Whereas other channels of reproduction were under political control, cultural and educational reproduction of intergenerational inequalities was still possible (Ganzeboom et al. 1990) . For school transitions under Communism, the odds of entry into the various types of upper secondary school, and the choice between the

Table 8.1: Main mechanisms of differentiation in Hungary

\begin{tabular}{|c|c|c|}
\hline & External (between schools) & Internal (within schools) \\
\hline \multirow[t]{4}{*}{ Formal } & Vocational tracking $^{a}$ & Specializations $^{\mathrm{a}}$ \\
\hline & $\begin{array}{l}\text { (apprenticeship/vocational training } \\
\text { and vocational secondary at age } 14 \text { ) }\end{array}$ & $\begin{array}{c}\text { One special school year dedicated to } \\
\text { learning languages }\end{array}$ \\
\hline & Early tracking (ages 10 and 12) ${ }^{\mathrm{a}}$ & Subjects on advanced levels \\
\hline & Non-public schools ${ }^{a}$ & \\
\hline \multirow[t]{2}{*}{ Informal } & 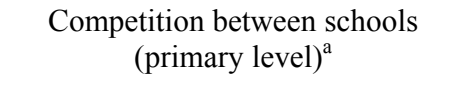 & $\begin{array}{c}\text { Teachers' characteristics in different } \\
\text { classes }\end{array}$ \\
\hline & & $\begin{array}{l}\text { Ability grouping (class } \\
\text { composition) }\end{array}$ \\
\hline
\end{tabular}


academic secondary school, vocational secondary school, or apprenticeship school were influenced most strongly by parental background. The transition from secondary to tertiary level was also influenced strongly by this school choice at age 14. As a result, the direct effect of social origin was smaller at the tertiary level transition point (Róbert 1991).

More recent studies have looked at the outcome differences between these tracks and argued that whereas there is a clear and strong selection of students between these tracks based on their ability and their social background, there is no observable performance difference between the academic secondary track and the vocational secondary track once this selection is accounted for (Horn et al. 2006). However, it is also argued that apprenticeship/vocational training tracks provide a smaller value-added in math or reading compared to the other two tracks (Hermann 2013). Thus tracking on upper secondary level intensifies differences between social classes.

Early tracking on the lower secondary level has similar consequences (Horn 2013). A prominent solution on the lower secondary level for the problems created by the demographic decline was to establish a six-year-long or even an eight-year-long academically oriented educational track. With such an institutional transformation, the better and more innovative schools tried to cream off the best students and thus avoid firing staff or closing down. This change - as was argued at the time - could also be more efficient from a pedagogical perspective, because pupils could achieve better in such tracks (see Liskó 1994; Horn 2010). Thus, basically the original four-year academic track was extended by the new six-year-long and eight-year-long academic tracks. In fact, these new school tracks shortened the years pupils spent in primary school from eight years to six or four years. Pupils (and families) had to choose which educational track to follow and what school to attend two or four years earlier. This resulted in early tracking at the ages of 10 or 12, but only for the top of the ability distribution. Note, however, that the previous 'Soviet-type' tracking at the age of 14 was and still is present for pupils at the bottom of the distribution (cf. apprenticeship/vocational training tracks).

The third form of external-formal tracking is tracking between public and non-public schools. A previous analysis of church-run schools in Hungary has shown that students in these schools perform better and have higher success rates for transition to higher education than students in public schools. This advantage persists after controlling for the dissimilar student composition in church-run schools (Dronkers and Róbert 2004).

External and informal differentiation is about school choice in Hungary. It is possible to choose schools both on the primary and on the secondary level. On the primary level, a district principle is in effect, meaning that schools have to take those students who live within their assigned catchment area. However, it is possible to apply to any other school, and the school principal 
has the right to decide whom to admit. ${ }^{4}$ On the secondary level, school choice and tracking - as described above - cannot be separated empirically. It has been argued that the inequality-increasing mechanism of school choice on the primary level is very important and follows a rather straightforward logic: at the early stages of the post-Communist transition, when the demographic decline hit hardest leading to the possibility of school choice, larger settlements tried to attract pupils from nearby villages to fill their empty places and avoid firing teachers. Naturally, only the more affluent parents (usually those with a motor car who were already working in the city) could afford to commute daily between the village and the city, and schools also more probably selected these students for obvious reasons. This created socially segregated schools first in the smaller villages, then within the multischool cities as well (see Kertesi and Kézdi 2009 for a detailed description of the mechanism, and 2013 for the empirical proof). Kertesi and Kézdi (2013, 27, Figure 2) show that segregation has increased tremendously within the last 15 years, and argue that this marked increase is due mainly to the increased possibility of school choice.

Internal and formal forms of differentiation can be the various possible specializations schools offer their students. These are either extra-curricular courses, held frequently in the afternoon hours after regular lessons on various subjects such as informatics or sports, or deliberately selected classes within a school cohort offering a higher number of lessons in a given subject during the teaching day, usually in math, Hungarian, or music. An important form of such within-school differentiation is the availability of specialized classes in foreign language training. Language training can also be provided in either (1) the so-called language-preparatory classes that offer an additional year of intensive language training between Grades 8 and 9 or (2) the so-called bilingual trainings in which this additional year is followed by teaching some subjects (e.g. math) in the given foreign language. Taking part in these within-school specializations is not cheap. Students receiving such extra-curricular or increased number of courses are likely to perform better. Thus there is a good chance that this internal and formal differentiation within schools contributes to the accumulation of educational opportunities. Unfortunately, no direct nationwide official statistics are available on this. However, just under 2.5 per cent of students in 8th grade were attending bilingual classes in 2012, whereas an additional 14 per cent were in classes with a specialization. These ratios go up to 5 per cent and 23 per cent respectively in 10th grade. Within-school specializations are a bit more prevalent in public schools than in the church-run schools, and much more prevalent than in private schools.

Internal and informal differentiation involves teachers' characteristics in different schools or classes as well as ability grouping. If observations made 
by Varga (2011) are correct, there is a self-selection of teachers into schools with higher student status or ability. Consequently, they play an important role in 'maintaining' inequalities in educational opportunities for students coming from various social backgrounds. Ability grouping, the other form of internal and informal differentiation, is practiced for certain subjects such as languages or math. Further types of grouping (e.g. based on ethnicity) are regarded as discrimination and are illegal. Official national statistics on ability grouping are hard to find. The PISA 2006 survey shows that about two-thirds of school principals reported using ability grouping in their school for at least one subject. However it is not clear what share of this figure refers to the formal specializations (described above) and how much to the informal differentiation of students.

\section{EMPIRICAL ANALYSIS}

\section{Datasets}

We utilize two interconnected datasets. The National Assessment of Basic Competencies (NABC) (see OECD 2010b) and the Hungarian Life Course Survey (HLCS) (see Kertesi and Kézdi 2010b). The NABC is a standardbased annual assessment designed similarly to the OECD PISA, but in which individuals can be followed up over the years. The NABC tests reading and mathematical literacy in 6th, 8th, and 10th grade. Although scores are standardized not only within but also across cohorts to a mean of 1500 and a standard deviation of 200, we report within-cohort standardized betas $(0$ mean and 1 standard deviation) so that the point estimates of test score and socio-economic status (see below) can be compared. Whereas reading and mathematics tests are conducted within school, students are also expected to take home a family background questionnaire to be completed by their parents. Although this makes the response rate somewhat lower than that in the OECD PISA survey, the available data are considered to be more reliable.

The official datasets also contain a socio-economic status index (SES) that is a $z$-standardized product of several variables describing the social, economic, and cultural background of the student. ${ }^{5}$

For the analysis below we pool three cohorts from 2008, 2009, and 2010. We run separate regressions for the 6th- and 8th-grade cohorts. All these cohorts were also surveyed two years later in 2010, 2011, and 2012 in 8th and 10th grade respectively. To interpret changes at the secondary level (especially between 8th and 10th grade), we have to consider that all earlier educational decisions contribute to this late educational choice. Because the parents of higher status students want to secure their advantage at an earlier 
stage (which is incorporated in pupils' human capital), we probably underestimate the impact of SES.

The HLCS dataset contains a representative subsample of the 8th-grade 2006 cohort from the NABC dataset. A total of 10022 students were sampled and followed through their education career in six waves. These six waves contain detailed information on the respondents' ethnicity, schools, family background (including poverty and home environment), as well as many other dimensions. We shall utilize this dataset to show the selectivity of the system between the lower and upper secondary level (between 8th and 9th grade), in the transitions between tracks within the secondary level, and in the transition from school to work or post-secondary education. ${ }^{6}$

\section{Allocation of Students (Research Question 1)}

As described above there are three potential external and formal differentiation mechanisms. Table 8.2 highlights the 'vocational tracking' mechanism between 8 th and 9th grade. The table shows that students who are already in the six- or eight-year-long academic tracks in 8th grade are much more likely to enter academic tracks one year later. These students have a much higher SES and also much higher test scores: the z-standardized SES and test score points of students in the early-selective tracks are more than one standard deviation higher than those of the average student.

Moreover, higher SES and higher test score students from the general track are more likely to enter the academic secondary tracks, whereas the lower SES and lower test score students are more likely to enter the apprenticeship/vocational training tracks. The difference between these tracks is more than one standard deviation in both SES and test scores. Students' SES and scores on vocational secondary tracks are very similar to those of the average student in the full population.

Table 8.2 also shows the percentage of students entering each track who had practiced school choice in the 1st grade of primary school (choice columns). The table shows that around 18 per cent of the cohort attended primary schools outside their catchment area. However, 36 per cent of students entering early selective tracks utilized this possibility of school choice. Naturally, we are unable to show the direction of causality. It is unclear whether school choice contributes to an earlier selection of these students - for example through better school-student matches that help children to develop faster - or whether the practice of school choice and the mechanism of early selection targets the same population, namely the higher status and more highly skilled students. 
Table 8.2: Distribution of students and their basic characteristics across school types in 8th and 9th grade

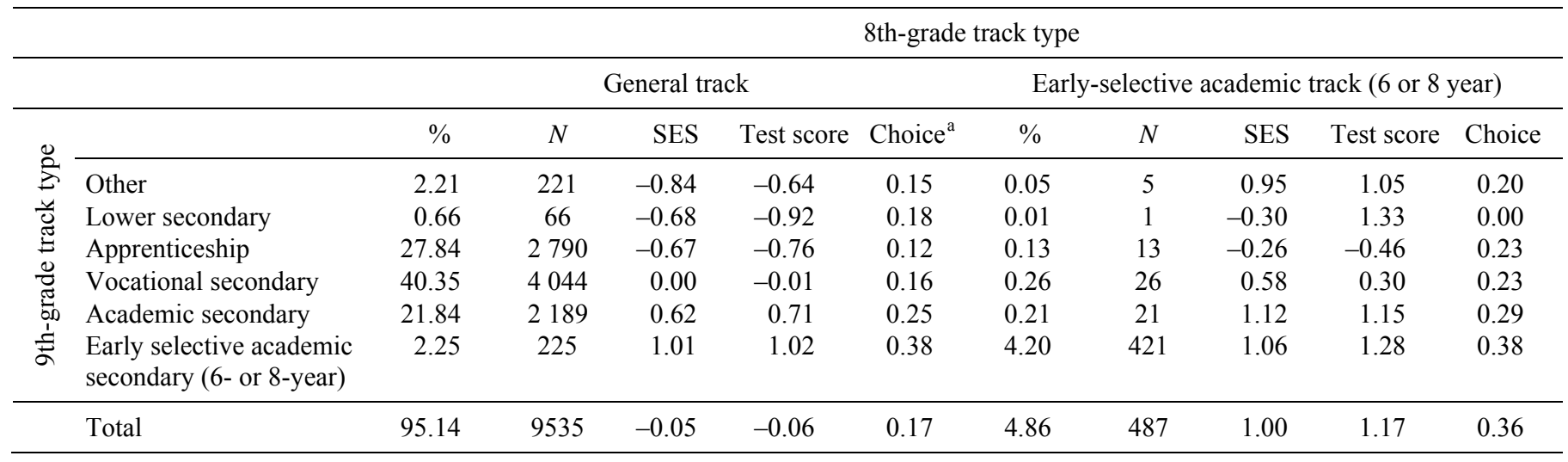

Source: Own calculations based on the HLCS.

Notes: ${ }^{\text {a }}$ Percentage of students entering each track who practiced school choice in 1st-grade primary school. 
Tables 8.3 and 8.4 show a different approach to the same question. Using the panel structure of the NABC dataset, we estimate the effect of family background and test scores on the transition into early-selective tracks on the lower secondary level (Table 8.3), the transition into vocational or academic tracks and non-public schools on the upper secondary level (Table 8.4), the practice of school choice on the lower secondary level (Table 8.3), and entering classes with some specialization (math, languages, arts, etc.) on the lower (Table 8.3) or upper secondary (Table 8.4) level. All estimations below include previous school fixed effects besides the individual level SES, test score, and gender controls. Although we admit that by using these fixed effects, we might over-control for unmeasured heterogeneity in the 6th-grade panel, ${ }^{7}$ we argue that these results are more conservative, and thus show a lower bound to the extent of inequality-increasing mechanisms in the Hungarian system.

The first and foremost conclusion from these analyses is that family background matters even after controlling for previous test scores. In almost all of these estimations, the effect of SES is comparable in size to, if not larger than, the effect of test score. For instance, a student who has a one standard deviation higher family background compared to another student with similar test scores from the same school has a 21.6 per cent higher chance of entering a six-year academic track, an 11.4 per cent higher chance of entering a church school, or a 5.8 per cent higher chance of entering a private school. One standard deviation higher SES predicts a 23.4 per cent lower chance of entering the apprenticeship/vocational training and a 15.7 per cent higher chance of entering the academic secondary track as opposed to the vocational secondary track. Whereas at first glance, it might seem surprising that lower SES families are more likely to enter private tracks on the upper secondary level, we note that anecdotal evidence suggests that the distribution of private schools is two-peaked: these schools compete both for the rich and provide elite training, whereas numerous foundation schools also try to fill a void left by the public education system and educate students who would otherwise drop out of the system.

The NABC also allows a rough estimation of the extent of within-school differentiation. Students in the questionnaire are asked about their specializations. The specialization columns show that family status matters in the internal differentiation as well. One standard deviation higher SES is associated with a 7 per cent increase on the lower and a 13 per cent increase on the upper secondary level in the chances of students being in a class with specialization. This is comparable in size with the effects of the externalformal non-public tracking mechanism. 
Table 8.3: Association of possible indicators of tracking with outcomes in 8th grade, fixed effect logit, and average marginal effects (standard errors in parentheses)

\begin{tabular}{|c|c|c|c|c|c|}
\hline & \multicolumn{3}{|c|}{ External and formal } & \multirow{2}{*}{$\frac{\text { External-informal }}{\text { Choice }^{\mathrm{d}}}$} & \multirow{2}{*}{$\begin{array}{l}\text { Internal-formal } \\
\text { Specialization }\end{array}$} \\
\hline & Early selection $^{\mathrm{a}}$ & Church $^{\text {b }}$ & Private $^{c}$ & & \\
\hline SES & $\begin{array}{l}0.216^{* *} \\
(0.004)\end{array}$ & $\begin{array}{l}0.114 * * \\
(0.005)\end{array}$ & $\begin{array}{c}0.058^{* *} \\
(0.011)\end{array}$ & $\begin{array}{l}0.046^{* *} \\
(0.002)\end{array}$ & $\begin{array}{l}0.071 * * \\
(0.003)\end{array}$ \\
\hline Test score, 6th grade & $\begin{array}{l}0.262^{* *} \\
(0.004)\end{array}$ & $\begin{array}{l}0.032 * * \\
(0.005)\end{array}$ & $\begin{array}{c}-0.080^{* *} \\
(0.010)\end{array}$ & $\begin{array}{l}0.032 * * \\
(0.002)\end{array}$ & $\begin{array}{c}0.097^{* *} \\
(0.002)\end{array}$ \\
\hline Female & $\begin{array}{l}0.035^{* *} \\
(0.005)\end{array}$ & $\begin{array}{c}-0.009 \\
(0.008)\end{array}$ & $\begin{array}{c}-0.024 \\
(0.016)\end{array}$ & $\begin{array}{c}0.003 \\
(0.003)\end{array}$ & $\begin{array}{l}0.020^{* *} \\
(0.004)\end{array}$ \\
\hline \multicolumn{6}{|l|}{ Cohort (ref. 2008) } \\
\hline $\begin{array}{l}2009 \\
2010\end{array}$ & $\begin{array}{c}0.008 \\
(0.006) \\
0.019 * * \\
(0.006)\end{array}$ & $\begin{array}{c}0.012 \\
(0.010) \\
0.202 * * \\
(0.010)\end{array}$ & $\begin{array}{c}0.020 \\
(0.020) \\
-0.018 \\
(0.021)\end{array}$ & $\begin{array}{c}0.003 \\
(0.003) \\
0.008^{*} \\
(0.004)\end{array}$ & $\begin{array}{c}-0.003 \\
(0.005) \\
0.019 * * \\
(0.005)\end{array}$ \\
\hline Previous school fixed effect & yes & yes & yes & yes & yes \\
\hline Observations & 181466 & 140170 & 42869 & 203773 & 155042 \\
\hline 6th grade school fixed effect & yes & yes & yes & yes & yes \\
\hline Log Likelihood & -32293 & -16119 & -3674 & -92831 & -50587 \\
\hline$\chi^{2}$ test & $15544 * *$ & $1347 * *$ & $78.77 * *$ & $1484 * *$ & $3886^{* *}$ \\
\hline Pseudo $R^{2}$ & 0.194 & 0.040 & 0.011 & 0.008 & 0.037 \\
\hline
\end{tabular}

Source: Own calculations based on the NABC 2012-2010, 2011-2009, and 2010-2008 panels.

Notes: $+p<0.10 * p<0.05, * * p<0.01$

Reference person: SES $=0$, Test score $=0$, Cohort: $2008=1$, Female $=0 ;{ }^{a}$ whether student is in a 6 - or 8 -year long academic track in 8 th grade; ${ }^{\mathrm{b}}$ whether student is in a church-run school in 8 th grade; ${ }^{\mathrm{c}}$ whether student is in a privately run school in 8 th grade; ${ }^{\mathrm{d}}$ whether student attends a school outside her or his residential catchment area in 8 th grade; ${ }^{\circ}$ whether student attends a class with specialization in one subject (math, languages, arts) in 8th grade. 
Table 8.4: Association of possible indicators of tracking with outcomes in 10th grade, fixed effect logit, and average marginal effects

\begin{tabular}{|c|c|c|c|c|c|}
\hline & \multicolumn{4}{|c|}{ External and formal } & \multirow{3}{*}{$\begin{array}{l}\text { Internal and formal } \\
\text { Specialization }^{\mathrm{e}}\end{array}$} \\
\hline & \multicolumn{2}{|c|}{ Vocational tracking } & \multicolumn{2}{|c|}{ Non-public tracking } & \\
\hline & $\begin{array}{l}\text { Voc./apprenticeship } \\
\text { track }^{\mathrm{a}}\end{array}$ & $\begin{array}{l}\text { Academic } \\
\text { track }^{\mathrm{b}}\end{array}$ & Church $^{\mathrm{c}}$ & Private $^{\mathrm{d}}$ & \\
\hline SES & $\begin{array}{l}-0.234 * * \\
(0.002)\end{array}$ & $\begin{array}{l}0.157^{* *} \\
(0.002)\end{array}$ & $\begin{array}{l}0.107 * * \\
(0.003)\end{array}$ & $\begin{array}{l}-0.006^{*} \\
(0.003)\end{array}$ & $\begin{array}{l}0.137 * * \\
(0.002)\end{array}$ \\
\hline Test score, 8th grade & $\begin{array}{l}-0.409 * * \\
(0.003)\end{array}$ & $\begin{array}{l}0.208^{* *} \\
(0.002)\end{array}$ & $\begin{array}{l}0.027 * * * \\
(0.003)\end{array}$ & $\begin{array}{l}-0.084 * * \\
(0.003)\end{array}$ & $\begin{array}{l}0.225^{* *} \\
(0.002)\end{array}$ \\
\hline Female & $\begin{array}{l}0.069 * * \\
(0.004)\end{array}$ & $\begin{array}{l}-0.062 * * \\
(0.003)\end{array}$ & $\begin{array}{l}-0.024 * * \\
(0.005)\end{array}$ & $\begin{array}{l}-0.003 \\
(0.005)\end{array}$ & $\begin{array}{l}-0.034 * * \\
(0.003)\end{array}$ \\
\hline \multicolumn{6}{|l|}{ Cohort (ref. 2008) } \\
\hline 2009 & $\begin{array}{l}0.006 \\
(0.005) \\
0.047 * * \\
(0.006)\end{array}$ & $\begin{array}{l}0.004 \\
(0.004) \\
-0.036^{* *} \\
(0.004)\end{array}$ & $\begin{array}{l}-0.000 \\
(0.006) \\
0.053^{* *} \\
(0.008)\end{array}$ & $\begin{array}{l}-0.005 \\
(0.006) \\
-0.002 \\
(0.008)\end{array}$ & $\begin{array}{l}0.045^{* *} \\
(0.004) \\
-0.018^{* *} \\
(0.004)\end{array}$ \\
\hline Observations & 205786 & 186072 & 172867 & 153830 & 210420 \\
\hline 8th grade school fixed effect & yes & yes & yes & yes & yes \\
\hline Log Likelihood & -53615 & -88615 & -35904 & -34075 & -93295 \\
\hline$\chi^{2}$ test & $56074 * *$ & $26486^{* *}$ & $1927 * *$ & $943.4 * *$ & $32914 * *$ \\
\hline Pseudo $R^{2}$ & 0.343 & 0.130 & 0.026 & 0.014 & 0.150 \\
\hline
\end{tabular}

Source: Own calculations based on the NABC 2012-2010, 2011-2009, and 2010-2008 panels.

Notes: See Table 8.3. 
Table 8.5: Percentage of students for whom these events have happened at least once through their secondary level education career (conditional probabilities)

\begin{tabular}{|c|c|c|c|c|c|c|}
\hline & \multirow[b]{2}{*}{ Events } & \multirow[b]{2}{*}{ Total population } & \multirow[b]{2}{*}{ Roma } & \multirow[b]{2}{*}{ Non-Roma } & \multicolumn{2}{|c|}{ Non-educated parents } \\
\hline & & & & & Roma & Non-Roma \\
\hline (1) & Grade repetition $^{\mathrm{a}}$ & 18 & 30 & 17 & 31 & 23 \\
\hline (2) & Grade repetition within school track ${ }^{\mathrm{a}}$ & 15 & 25 & 14 & 26 & 19 \\
\hline (3) & Secondary $^{\mathrm{b}} \rightarrow$ Apprenticeship & 13 & 30 & 12 & 34 & 30 \\
\hline (4) & Apprenticeship $\rightarrow$ Secondary $^{\mathrm{b}}$ & 25 & 13 & 28 & 11 & 19 \\
\hline (5) & Academic $\rightarrow$ Vocational secondary & 11 & 17 & 10 & 12 & 19 \\
\hline (6) & Vocational Sec. $\rightarrow$ Academic & 8 & 6 & 9 & 4 & 6 \\
\hline (7) & Full time ed. $\rightarrow$ Dropout & 5 & 28 & 4 & 34 & 15 \\
\hline (8) & Full time ed. $\rightarrow$ Night school & 2 & 6 & 1 & 6 & 2 \\
\hline (9) & Night school $\rightarrow$ Dropout & 45 & 78 & 30 & 84 & 68 \\
\hline (10) & Dropout $\rightarrow$ Dropout & 82 & 89 & 76 & 90 & 88 \\
\hline (11) & Dropout $\rightarrow$ Full time ed. & 14 & 8 & 19 & 9 & 12 \\
\hline (12) & Dropout $\rightarrow$ Night school & 4 & 2 & 5 & 2 & 2 \\
\hline (13) & Night school $\rightarrow$ Full time ed. & 37 & 15 & 47 & 10 & 12 \\
\hline
\end{tabular}

Source: Kertesi-Kézdi 2010a, Table 7, HLCS 2006-2009, four waves.

Notes: Night school $=$ night schooling, distant schooling, or individually designed curricula. ${ }^{\text {a }}$ Multiple year repetitions are counted as one; ${ }^{\mathrm{b}}$ Secondary $=$ Academic secondary and vocational secondary. 


\section{The Lack of a Second Chance (Research Question 2)}

Table 8.5 reports the percentage of students in whom one of the listed events has ever occurred during their secondary school career. Note that this might be an overestimation of the fluidity of the system, because it counts all movements irrespective of their direction. ${ }^{8}$

Table 8.5 underlines the lack of a second chance in Hungarian public education. The events in Rows 7 to 10 (in italics as in the original) depict the channels that lead to dropping out of the system, whereas Rows 11 to 13 are those that lead back to the system. 'Tendencies are clear: when the chance of dropping out from full-time education is small (4-5 per cent) - as for the non-Roma students and for the full population - the chance of returning back to the system is also small (14-19 per cent). However, when there is a real stake - for the Roma students and especially for Roma students with noneducated parents who have a high chance of dropping out from full time education (28-34 per cent) - the chance of returning to the system is tiny (89 per cent)' (Kertesi and Kézdi 2010b, 390, own translation).

Nevertheless, it also seems that the initial allocation of students is not entirely permanent: there is non-negligible movement between tracks during these four years. For instance 25 per cent of students who were ever enrolled in the apprenticeship/vocational training track have also moved to a secondary (academic or vocational) track during their school career. However whereas the 'upward' movements are similar or larger in size for the total population, the 'downward' movements are much more prevalent for the Roma or the low-status population.

\section{Short- and Long-Term Effects (Research Question 3)}

Using the NABC dataset, both Horn (2013) and Hermann (2013) have confirmed differences between the short-term effects of various tracks. Horn (2013) has argued that the early-selective academic tracks increase students' 10th-grade test scores compared to those of very similar students in other tracks. Hermann (2013) has pinpointed that students who apply to vocational secondary tracks but are instead accepted only to vocational training tracks perform worse in 10th grade than very similar students who are admitted to the vocational secondary track. So it seems that early tracking and vocational tracking both have harmful short-term effects on educational equalities. However, no comparable findings are available on long-term effects.

Recently Gurzó and Horn (2015) have shown that there are no visible effects of early tracking on average labour market outcomes. That is, the introduction of early tracking during the post-Communist transition has not increased the average probability of employment, the average probability of 
Table 8.6: Percentage distribution of students in the different tracks six years after upper secondary track entry

\begin{tabular}{lcccccc}
\hline $\begin{array}{l}\text { 9th-grade track } \\
\text { type }\end{array}$ & Working & $\begin{array}{c}\text { Unem- } \\
\text { ployed }\end{array}$ & $\begin{array}{c}\text { Study- } \\
\text { trainee }\end{array}$ & Other & Total & $\begin{array}{c}\% \text { in } \\
\text { population }\end{array}$ \\
\hline Other & 10.99 & 28.38 & 44.32 & 16.32 & 100 & 1.7 \\
Lower sec. & 29.41 & 30.77 & 29.64 & 10.18 & 100 & 0.4 \\
Apprenticeship & 41.23 & 24.84 & 20.25 & 13.68 & 100 & 21 \\
Vocational sec. & 24.16 & 15.85 & 51.98 & 8.01 & 100 & 41.4 \\
Academic sec. & 11.26 & 5.55 & 77.82 & 5.37 & 100 & 27.1 \\
Early selective & 8.54 & 3.05 & 85.36 & 3.05 & 100 & 8.4 \\
academic sec. & & & & & & \\
(6 or 8 year) & & & & & & \\
Total & 22.72 & 14.14 & 54.92 & 8.21 & & \\
\hline
\end{tabular}

Source: Own calculations based on the HLCS.

unemployment, or the level of wages. This, however, does not mean that early tracking has not had an impact on inequalities: a non-changing level of employment or wages might easily mask increasing differences between different groups. Employment chances or wages might have increased for one and decreased for another group. Their result shows only that early selection was not a Pareto optimal policy and suggests that early tracking has a heterogeneous effect on different sub-populations.

Although we are unable to test the long-term causal effect of tracking, the HLCS can be used to indicate long-term differences between groups that are probably due, at least partially, to sorting. Table 8.6 shows the raw differences without controlling for any other predictor in 2012 - six years after upper secondary entry and two years after the potential graduation date - between students who were in different tracks in 2006. It is relatively hard to judge the success of different tracks in terms of an increase in employment chances or enrolment to university due to their different student intake as well as their different aims. However, it is obvious that students entering the early selective academic tracks are more likely to be studying, whereas apprenticeship/vocational track graduates are much more likely to be unemployed than graduates from vocational secondary.

Table 8.7 goes one step further and assesses marginal differences between tracks ceteris paribus family status and test scores in 8th grade using a multinomial probit estimation. As expected, higher status and higher skills contribute significantly to further studies.

Also, as expected, students in academic secondary and early-selective tracks are 15 to 17 per cent more likely to study than the similarly skilled and 
Table 8.7: Marginal track differences in outcomes six years after upper secondary entry, multinomial probit

\begin{tabular}{lcccc}
\hline & Work & Unemployed & Study & Other \\
\hline SES & $-0.036^{* *}$ & $-0.066^{* *}$ & $0.135^{* *}$ & $-0.033^{* *}$ \\
& $(0.008)$ & $(0.008)$ & $(0.010)$ & $(0.005)$ \\
Test score & $-0.044^{* *}$ & $-0.065^{* *}$ & $0.122^{* *}$ & $-0.013^{* *}$ \\
& $(0.009)$ & $(0.008)$ & $(0.010)$ & $(0.006)$ \\
Other & $-0.139^{* *}$ & 0.037 & 0.036 & $0.066^{*}$ \\
& $(0.033)$ & $(0.038)$ & $(0.056)$ & $(0.036)$ \\
Lower secondary & 0.027 & 0.038 & -0.064 & -0.001 \\
& $(0.082)$ & $(0.071)$ & $(0.088)$ & $(0.042)$ \\
Apprenticeship & $0.138^{* *}$ & 0.007 & $-0.172^{* *}$ & $0.027^{* *}$ \\
& $(0.019)$ & $(0.015)$ & $(0.019)$ & $(0.012)$ \\
Secondary track & & & & \\
(ref. Vocational) & & & & \\
Academic & $-0.090^{* *}$ & $-0.059^{* *}$ & $0.146^{* *}$ & 0.003 \\
& $(0.016)$ & $(0.014)$ & $(0.020)$ & $(0.012)$ \\
Early-selective & $-0.091^{* *}$ & $-0.073^{* *}$ & $0.174^{* *}$ & -0.010 \\
& $(0.026)$ & $(0.029)$ & $(0.034)$ & $(0.020)$ \\
\hline Observations & 7057 & 7057 & 7057 & 7057 \\
\hline
\end{tabular}

Source: Own calculations based on the HLCS.

Notes: $+p<0.10,{ }^{*} p<0.05,{ }^{* *} p<0.01$. Standard errors in parentheses.

Marginal effects for a vocational secondary track student, who has an average socioeconomic status $(\mathrm{SES}=0)$ and average test score $($ Test score $=0)$.

similar status vocational secondary graduate. This effect is comparable to the effect of a one standard deviation increase in test scores or in status. Apprenticeship/vocational training graduates are more likely to work than vocational secondary graduates but are less likely to study. There is no difference between these tracks in unemployment probabilities.

All in all it seems that tracks do what is formally/officially expected from them: apprenticeship tracks increase employment probabilities, whereas academic tracks increase the chance of further studies - at least two years after expected graduation.

\section{DISCUSSION AND CONCLUSION}

This chapter has highlighted the main mechanisms that lead to the rather large inequality of opportunity (OECD 2010a) of the Hungarian public education system. Based on the summarized literature, we have argued that at 
least five important mechanisms contribute to the level of inequality. Competition between primary level schools for high-status students generates status-segregated schools within the system (see Kertesi and Kézdi 2009, 2013). Early tracking on the lower secondary level is also likely to add to this segregation (see Horn 2013), whereas vocational tracking on the upper secondary level further aggravates differences (Hermann 2013). Besides these mechanisms, differences between public and non-public education providers (Dronkers and Róbert 2004) as well as within-school separation of students are also probable generators of inequalities.

Whereas the empirical analyses provided in this chapter are certainly not causal, we reckon they are indicative of the sheer size of the problem. All of these mechanisms differentiate between students based on their family status even when we take the initial skills of the students into account. In fact the size of the SES effect is at least as large - if not larger - than the size of the test scores. This suggests that it is not solely the ability of the students that is decisive for school placement but also their social status.

Using results from other sources, we have also highlighted that although the initial track placements are not carved in stone, and there is a significant amount of between-track mobility, the lack of a second chance is alarming. Students, especially Roma students and students with non-educated parents, have a very low chance of returning to the system once they have dropped out.

\section{NOTES}

1 Nonetheless a few traditional, church-run schools were allowed to operate even during the Communist era.

2 Parts of this law came into force in September 2012; others, in September 2013.

3 For some qualitative information and evidence based on small-scale surveys, see Eröss and Kende (2008).

4 Whereas in general, the schools outline the admission criteria for all out-of-district students such as previous performance, siblings already enrolled in the school, or social status - the final admission decision is the sole responsibility of the principal.

5 The variables used to generate the SES index are highest parental education, parent's labour market status, books at home, available personalties at home (TV, washing machine, car, mobile telephone), devices to assist in learning at home (computer), and family participation in cultural activities (see Hermann and Molnár 2008 in Hungarian)

6 For more detail on the HLCS in Hungarian, see Kertesi and Kézdi (2010b).

7 By using school fixed effects, our estimates are based only on observations in which the school changed between grades. This is more restrictive between 6th and 8th grade, because most students change school between 8 th and 10th grade anyway.

8 For instance, if a student moves from vocational secondary to apprenticeship/vocational training and then later moves back, this appears as two events in Table 8.5, whereas in another statistic, it would appear as a permanent allocation (cf. start and finish in vocational secondary). 


\section{REFERENCES}

Bukodi, E. and P. Róbert (2008), 'Hungary', in I. Kogan, M. Gebel and C. Noelke (eds), Europe Enlarged: A Handbook of Education, Labour and Welfare Regimes in Central and Eastern Europe, Bristol, England: Policy Press, 183-211.

Dronkers, J. and P. Róbert, (2004), 'Has educational sector any impact on school effectiveness in Hungary? A comparison of the public and the newly established religious grammar schools', European Societies, 6 (2), 205-36.

Erőss, G. and A. Kende, (2008), Túl a Szegregáción - Kategóriák Burjánzása a Magyar Közoktatásban. Budapest, Hungary: L'Harmattan.

Ganzeboom, H.B.G., P.M. De Graaf and P. Róbert, (1990), 'Reproduction theory on Socialist ground: Intergenerational transmission of inequalities in Hungary', in A. L. Kalleberg (ed.), Research in Social Stratification and Mobility, Greenwich, CT: JAI Press Inc., 79-104.

Hermann, Z. (2013), 'Are you on the right track? The effect of educational tracks on student achievement in upper-secondary education in Hungary' Budapest Working Papers, 2013 (3), 1-57.

Hermann, Z. and T.L. Molnár (2008), 'Országos Kompetenciamérési adatbázis' Accessed 29 December 2011 at http://adatbank.mtakti.hu/files/ dokum/7.pdf

Horn, D. (2010), 'The political background of structural changes in the educational system of Hungary, 1985-1994', Center for Policy Studies Working Paper (2010/1):45

Horn, D. (2013), 'Diverging performances: The detrimental effects of early educational selection on equality of opportunity in Hungary' Research in Social Stratification and Mobility, 32, 25-43.

Horn, D. I. Balázsi, S. Takács and Y. Zhang (2006), 'Tracking and inequality of learning outcomes in Hungarian secondary schools' Prospects, 36 (4), 433-46.

Gurzó, Klára and Dániel Horn (2015) 'A korai iskolai szelekció hosszú távú hatása: egy közpolitikai kísérlet tanulságai.' Közgazdasági szemle, 62(október), 10701096.

Kertesi, G. G. Kézdi (2009), ‘Általános Iskolai Szegregáció Magyarországon Az Ezredforduló Után’, Közgazdasági Szemle 56 (November), 959-1000.

Kertesi, G. and G. Kézdi, (2010a), 'Segregation of primary schools in Hungary. A descriptive study using data from the National Assessment of Basic Competences of 2006', in The Hungarian Labour Market. Budapest, Hungary: IE-HAS, 99-119.

Kertesi, G. and G. Kézdi (2010b), 'Iskolázatlan Szülők Gyermekei És Roma Fiatalok a Középiskolában - Beszámoló Az Educatio Életpálya-Felmérésének 2006 És 2009 Közötti Hullámaiból', in Társadalmi Riport 2010, Budapest, Hungary: Tárki, 371407

Kertesi, G. and G. Kézdi (2013), 'School segregation, school choice and educational policies in 100 Hungarian towns', Budapest Working Papers (12): 1-134.

Liskó, I. (1994), ‘Átalakuló Iskolák', Educatio, 3 (1), 77-88.

Mare, R. D. (1981), 'Change and Stability in Educational Stratification'. American Sociological Review 46. 72-87.

Ministry of Human Resources (2013), 'Statisztikai Tájékoztató, Oktatási Évkönyv, 2012/2013'.

OECD (2004), Education at a Glance 2004, Paris, France: OECD. 
OECD (2010a), PISA 2009 Results: Overcoming Social Background - Equity in Learning Opportunities and Outcomes Vol. II., Paris, France: OECD.

OECD (2010b), OECD Review on Evaluation and Assessment Frameworks for Improving School Outcomes - Hungary Country Background Report, Paris, France: OECD.

Róbert, P. (1991), 'Educational transition in Hungary from the post-war period to the end of the 1998s', European Sociological Review 7 (6), 213-36.

Simkus, A. and R. Andorka (1982), 'Inequalities in educational attainment in Hungary, 1923-1973', American Sociological Review 47 (6), 740-51.

Varga, J. (2011), ‘A Tanárok Elosztása a Különböző Szociokulturális Hátterủ Tanulókat Tanító Iskolák Között', in Oktatás és Foglalkoztatás, Budapest, Hungary: KTI könyvek, 65-82. 